$\begin{array}{cl}\text { Türkiye Tarımsal Araştırmalar Dergisi } & \text { Turk J Agric Res } \\ \text { dergipark.gov.tr/tutad } & \text { 2017, 4(2): 109-123 } \\ \text { O TÜTAD } & \text { ISSN: 2148-2306 } \\ \text { e-ISSN: 2528-858X } & \text { doi: 10.19159/tutad.310568 }\end{array}$

\title{
Çanakkale İli Ezine İlçesi Arazi Kullanım Etkinliğinin Değerlendirilmesi
}

\author{
Timuçin EVEREST* \\ T.C. Glda Tarım ve Hayvancılık Bakanlığl, Çanakkale İl Gıda Tarım ve Hayvancılık Müdürlüğ̈̈, \\ Ezine İlçe Gıda Tarım ve Hayvancılık Müdürlüğ̈̈, Ezine-Çanakkale, TÜRKIYYE
}

Geliş Tarihi/Received: 17.11 .2016

Kabul Tarihi/Accepted: 23.01 .2017

*Sorumlu Yazar/Corresponding Author: timucineverest@gmail.com

Özet: Bu çalışmada; yaklaşık $721 \mathrm{~km}^{2}$ yüzölçümüne sahip Çanakkale ili Ezine ilçesinde arazi kullanımının etkinliği coğrafi bilgi sistemleri (CBS) ve uzaktan algılama teknikleri kullanılarak belirlenmişsir. Çalışmada, Çanakkale İl Envanter raporuna ait 1982 y1lı verileri ve 2012 yılı ASTER uydusu görüntüsü kullanılmıştır. Arazi kullanım etkinliğinin belirlenmesi için 1982 ve 2012 yılı temel arazi kullanım türleri (AKT) (tarım, mera, orman, su yüzeyi ve tarım dışı) ile raster formatına dönüştürülen arazi kullanım kabiliyet (AKK) sınıflarının kıyaslanması yapılmışı̧ı. Yapılan kıyaslama ile arazi kullanım türlerinin hangi arazi kullanım kabiliyet sınıfı içinde yer aldığı belirlenmiştir. Çalışma sonucunda; 30 yıllık zaman diliminde tarım, mera, tarım dışı ve su yüzeylerinde artış, orman alanlarında azalma görülmüş; I., II., III. ve IV. sınıf arazilerde tarım dışı kullanım 1982 yılında 665 ha iken, 2012 yılında bu değer \% 30 artarak 865.15 ha olmuștur. VI., VII. ve VIII. sınıf arazilerde ise tarım dışı alanlar 1683 ha iken \% 5.03 artarak 1767.5 hektara ulaşmıştır. VI. ve VII. sınıf arazilerdeki orman alanlarının azalması ile özellikle tarım ve mera kullanımındaki artışlara sebep olmuş; bu artışın, erozyona bağlı toprak kaybının artmasına neden olacağı düşünülmektedir.

An ahtar Kelimeler: Ezine, arazi kullanım, etkinlik, CBS

\section{Assessment of Land Use Efficiency in Ezine District of Çanakkale}

\begin{abstract}
In this study land use efficiency on Ezine District of Canakkale Province which covers approximately $721 \mathrm{~km}^{2}$ was determined with geographical information systems (GIS) and remote sensing techniques. In the study, 1982 year data of the Canakkale Provincial Inventory report and 2012 AST ER satellite image were used. To de termine the land use efficiency, basic land use types (agriculture, pasture, forest, water surface and non-agricultural areas) of 1982 and 2012 images were compared with land use capability classes converted to raster format. With this comparison, it was determined in which land use capability class the land use classes were included. According to results, it was detected that agriculture, pasture, wat er surfaces and non-agricultural areas were increased and forest areas were decreased in 30 years' period. While nonagricultural uses in I., II., III. and IV. class lands were 665 ha, it was increased approximately by $30 \%$ and reached to 865.15 ha in 2012. Non-agricultural uses in VI., VII. and VIII. class lands were 1683 ha in 1982 and it has increased about $5.03 \%$ and reached to 1767.5 ha in 2012. The decline of forest areas in VI and VII class land has led to increases especially in agriculture and pasture use. This increase is thought to lead to increased soil loss due to erosion.
\end{abstract}

Keywords: Ezine, land use, efficiency, GIS

\section{Giriş}

Doğal kaynakların envanterlerinin detaylı bir şekilde bilinmesi, bu kaynakların yönetilmesi ve planlanması açısından gerekli bir faktördür. Sınırlı olan doğal kaynakların (toprak, su, hava, canlılar, maden yatakları vb.) sürdürülebilir şekilde

kullanılabilmesi için mutlaka planlamalar yapılmas1 gerekmektedir. Arazi kullanımlarının faydalanıcılara sürdürülebilir bir şekilde yararlı olması için yetenekleri ve özellikleri doğrultusunda kullanılması gerekmektedir. 
Arazi ve toprak kelimeleri iki farklı kavramı ifade etmektedir. Tarımsal faaliyetlerdeki yeri düşünüldüğünde arazi ve toprak kavramı eş anlamlı kelimeler gibi görünmektedir. Arazi; büyük ölçüde arazi kullanım potansiyelini etkileyen iklim, jeoloji, rölyef, toprak, hidroloji ve bitki örtüsü gibi fiziksel çevreden oluşmaktadır. Toprak ise, arazinin bir parçasını oluşturmaktadır (Anonymous, 1976). Arazi kavramı tarım, orman, mera, şehir, tarım dışı vb. çok geniş bir kullanımları ifade etmektedir.

İşlenebilir tarım, mera, orman, yaban hayat1, turizm, kentsel gelişme ve şehirleşme için talep edilen araziler mevcut kullanılabilir arazi kaynaklarından daha fazladır. Gelişmekte olan ülkelerde bu kullanım durumları için talep edilen alanlar her geçen yıl katlanarak artmaktadır. Hızla artan dünya nüfusuna göre araziler yetersiz miktarda olup, kimi kullanıcılar için ise faydalı özellikleri bakımından kullanışsız durumdadır (Anonymous, 1993).

Arazilerin daha efektif biçimde kullanılması için yetenek ve özellikleri doğrultusunda planlamalar yapılmalı ve istenen kullanım türlerinin uygun alanlar üzerinde tesis edilmesi sağlanmalıdır. Tarım topraklarının plansız șekilde amacı dışında kullanılmaları arazide geri dönüşümü mümkün olmayan degradasyonlara neden olmaktadır. Türkiye'de kaybedilen arazi varlığ 1 ; I., II. ve III. sinıf arazilerde toplam 573239 hektara ulaşmıştır (Cangir ve ark., 1998; Dengiz ve ark., 2006).

Arazi sınıflarının tespit edilerek belirlenmesi için gerçekleştirilen toprak etüt çalışmaları ve yapılan analizlerin sonuçlarına göre yorumlamalar yapılmaktadır. Arazi kullanım kabiliyet sınıflaması arazilerin tarımsal üretime uygunluklarının yorumlanması için kullanılan temel argümanlardan birisidir. Başka bir ifadeyle Arazi Kullanım Kabiliyet sınıflaması (AKK), gerçekleştirilmiş olan bir toprak etüdünün kullanıcılar tarafindan daha kolay şekilde yorumlamasında yardımcı olmaktadır.

Mevcut arazi kullanım türlerinin, arazi kullanım kabiliyet sınıfları ile değerlendirilmesi arazilerin kullanım etkinliği belirlenmesinde çok önemli rol oynamaktadır. $\mathrm{Bu}$ kapsamda literatür incelendiğinde arazi kullanım etkinliği ile ilgili çalışmalar bulunmaktadır. Akbulak ve ark. (2010), Çanakkale-Karamenderes ovasında gerçekleştirdikleri çalş̧mada 1985 ve 2007 yıllarına ait arazi kullanım türlerini arazi kullanım kabiliyet sınıflamasına göre kıyaslamışlar; yapılan araştırma neticesinde Karamenderes ovasinda tarım alanlarının azaldığını bunun aksine orman, mera-otlak ve diğer arazi (şehir, nehir yatakları, maden ocakları, kumullar gibi) sınıflarının arttığını belirlemişlerdir.

Everest ve ark. (2011), Edirne ili Havsa ilçesinde uydu görüntüleri ve coğrafi bilgi sistemini kullanarak arazi kullanım etkinliğini belirlemişlerdir. Arazi kullanım türleri, 1993 ve 2008 yılı uydu görüntüsünün siniflaması sonucu elde edilen arazi kullanım türleri ile arazi kullanım kabiliyet sınıflarının kıyaslandı $\breve{g}_{1}$ çalışmanın sonucunda; I., II. ve III. sinıf tarım arazilerinde şehirleşme ve amaç dışı kullanımın arttığı ortaya konmuştur. Benzer durum, Dengiz ve Turan (2014) tarafindan Samsun ili Merkez ilçesinde gerçekleştirdikleri çalışmalarının sonucunda da rapor edilmiş tir.

$\mathrm{Bu}$ çalış̧mada; ilk aşamada istatistik, arşiv verileri ile uydu görüntüleri kullanılarak Ezine ilçesindeki arazi kullanımın 1982 ve 2012 yılları arasındaki zamansal değişiminin belirlenmesi; ikinci aşamada ise belirlenen kullanım türleri, arazi kullanım kabiliyet sınıfları ile kıyaslanarak bu arazilerin kullanım etkinliğinin belirlenmesi amaçlanmıştır.

\section{Materyal ve Yöntem}

\subsection{Materyal}

Ezine, $39^{\circ} 58^{\prime} 12^{\prime \prime}-39^{\circ} 47^{\prime} 48^{\prime \prime}$ kuzey enlemleri ile $26^{\circ} \quad 07^{\prime} \quad 48^{\prime \prime}-26^{\circ} \quad 30^{\prime} \quad 36^{\prime \prime}$ doğu boylamlan arasinda yer almakta ve 72187 hektar alan kaplamaktadır (Şekil 1). Ezine ilçesi Çanakkale iline $43 \mathrm{~km}$ mesafede olup, 1 belediye, 1 belde ve 48 köy olmak üzere toplam 50 yerleşim bölgesinden oluşmaktadır. Türkiye İstatistik Kurumu (TÜİK)'nun 2015 yılı adrese dayalı nüfus kayıt sistemi verilerine göre, Ezine ilçesinde toplam 31801 kişi bulunmakta ve bu nüfusun; 14056's1 ilçe merkezinde, 17745 ' 1 ise kırsal alanda yaşamaktadır (Anonim, 2015a).

Ezine, Marmara ve Ege Bölgeleri'nin geçiş alanındadır. $\mathrm{Bu}$ bakımdan iki bölgede görülen iklimin geçiş bölgesi konumundadır. Yazları sıcak ve kurak, kışları ise 1 lık ve yağışlı geçen bölgede, yağışlar genellikle yağmur şeklinde görülür. Kış aylarında zaman zaman kısa sürelerle kar yağmaktadır. Bölgede en soğuk ay Ocak ve Şubat ayları olup, en soğuk ay ortalamas $1-4{ }^{\circ} \mathrm{C}$ ile $-5^{\circ} \mathrm{C}$ derecedir. En sicak ay ise Temmuz ve Ağustos ayları olup, en sicak ay ortalamas $125^{\circ} \mathrm{C}$ ile $35^{\circ} \mathrm{C}$ derece arasındadır. Yıllık yağış açısından en yağışlı aylar Kasım, Aralık, Mart ve Nisan aylarıdır. Ortalama yağış miktarı yılda 626 mm'dir. Yağışın en az olduğu aylar ise Temmuz ve Ağustos aylarıdır (Anonim, 2015b). Havzanın iklimi, Thornthwaite (1948) iklim siniflandırmasına göre; C1,B'2,s2,b’3 yarı kurak, 


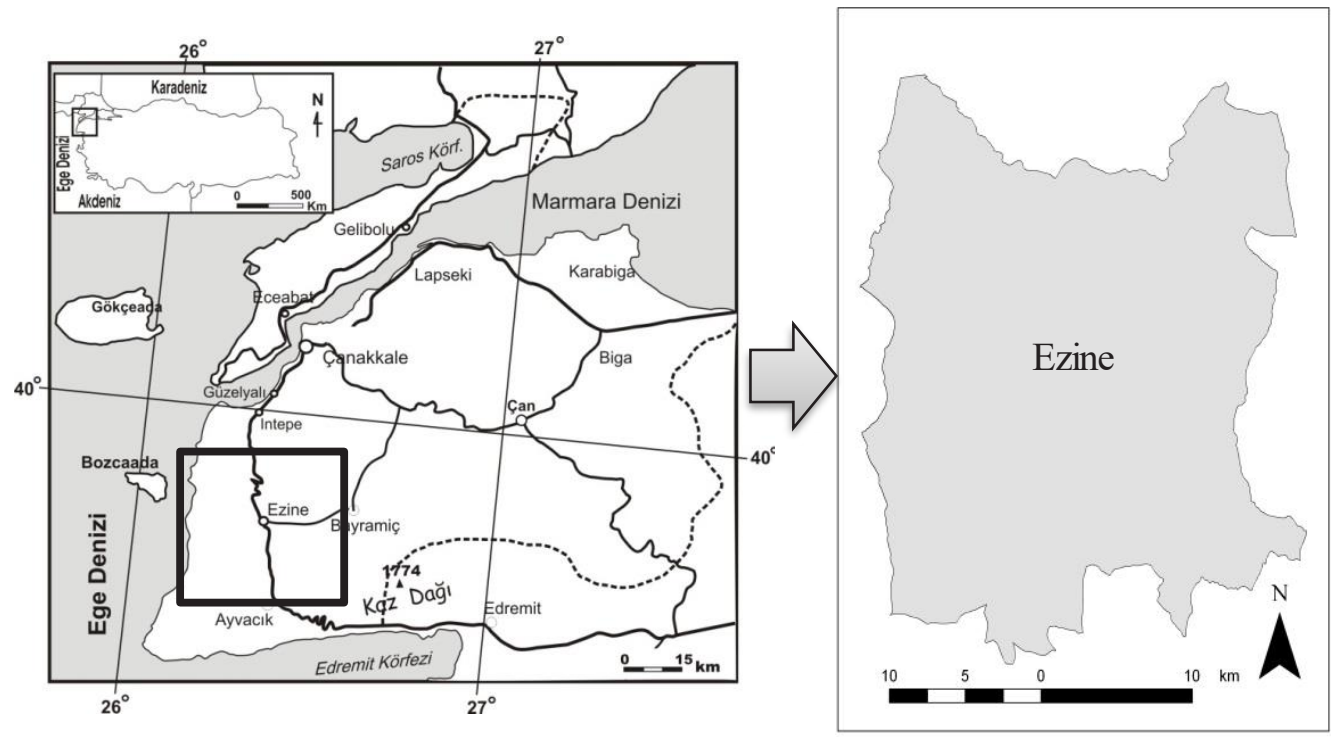

Şekil 1. Çalışma alanı

az nemli, mezotermal, su fazlası kış mevsiminde ve çok kuvvetli, yaz buharlaşma oranı \% 53 olan iklim tipine girmektedir.

Ezine ilçesi tarımsal anlamda önemli bir potansiyele sahiptir. Bölge bitkisel ve hayvansal üretim merkezlerinden biri olup, önemli miktarda üretim değerleri bulunmaktadır. Bölgede yoğun olarak serin iklim tahılları (buğday, arpa, çavdar ve yulaf), ayçiçeği, çeltik, yonca, fiğg, silajlık ve tohumluk misır, zeytin, bazı sert ve yumuşak çekirdekli meyve türleri ile kışlık (lahana, sspanak, marul) ve yazlık sebzeler (domates, biber, patlican, kavun, karpuz) yetiştirilmektedir. Bölge mera varlığı ve hayvancilık faaliyeti ile "Ezine Peyniri" markası ve coğrafi işaretine sahip bir alandır.

Ezine ilçesi toprak kaynakları incelendiğinde; çalışma alanı kuzeyinde bulunan Karamenderes ovasında, toprak taksonomisine göre Entisols, Vertisols, Inceptisols, Alfisols ordolarında; World Reference Base (WRB) siniflama sistemine göre Fluvisols, Cambisols, Luvisols, Vertisols, Calcisols, Gleysols siniflarinda topraklar bulunmaktadir (Everest, 2015). Karamenderes ovası dışındaki alanlarda ise Anonim (1999)'e göre; alüviyal, kolüvyal, kahverengi orman, kireçsiz kahverengi orman, kırmızı kahverengi akdeniz ve kireçsiz kahverengi büyük toprak gruplarına ait topraklar bulunmaktadır.

Çalışma alanında ovarsu ovaları (Karamenderes Ovası ve Alemşah Ovası) kuvaterner alüvyonlardan oluşmaktadır. Dalyan,
Körüktaş1 ve çevresi oligosende gelişmiş granodioritleri barındırmaktadır. Truva Tarihi Milli Parkı'nın güney doğusu metamorfik kristalin şist ve mermer kayaçlarından oluşturmaktadır. Çamlica ve Ezine merkezinin güneyinde ise paleozoik zamanda oluşmuş şistler yer almaktadır. Diğer alanlarda ise üst miyosende oluşmuş karasal kırıntılar bulunmaktadır (Kayan, 2000). Ezine ilçesinde yükseklik verileri denize komşu olan bölgelerde 0 metre kotundan Çı̆̆n tepesinde 500 m kotuna ulaşmaktadır (Şekil 2).

Çalışmada temel kartografik materyal olarak; (Mülga) Köy Hizmetleri Genel Müdürlüğü (KHGM) tarafindan 1999 y1lı il envanter raporu sonucu üretilmiş olan sayısal toprak haritas1, çalışma alanını kapsayan $1 / 25.000$ ve $1 / 100.000$ ölçekli topoğrafik haritalar ile 2012 yılı Mayıs ayına ait ASTER uydusu görüntüsü kullanılmıștır. Çalışmada uydu görüntüsünün işlenmesi ve sinıflandırmaların yapılması için Erdas Imagine 9.0, piksel bazlı sınıflama, sonuç haritalarının oluşturulması ve istatiksel verilerin ortaya konması için ArcGIS 9.3 yazılımları kullanılmıştır.

\subsection{Yöntem}

Çalışma alanını kapsayan topoğrafik haritalar tarayıc1 ile taranarak bilgisayar ortamına aktarılmıştır. Uydu görüntüsü bilgisayar ortamına aktarıldıktan sonra görüntünün geometrik olarak düzeltilmesi için topoğrafik harita verileri kullanılarak rektifikasyon işlemi uygulanmıştır. Rektifikasyon işleminde uydu görüntüsü üzerinden 


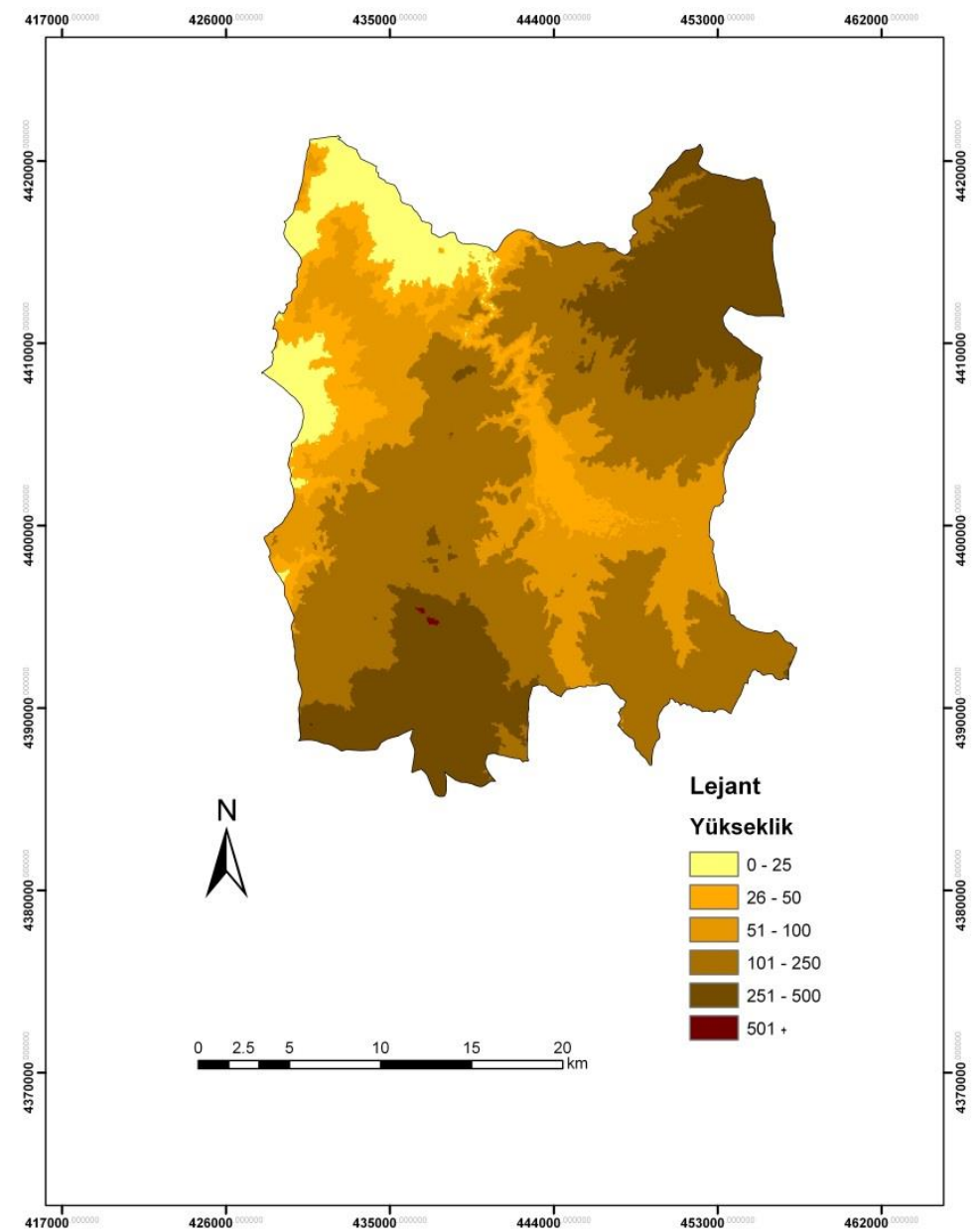

Şekil 2. Çalışma alanı yüks eklik haritası

rahatlikla bulunup tanımlanabilecek alanlar seçilmiş ve bu alanlara ait koordinat değerleri topoğrafik haritadan okunarak Erdas ortamına manuel olarak girilmiş ve geometrik düzelteme işlemi tamamlanmıştır. Ezine ilçesi sınırları uydu görüntüsü üzerinden kesilerek çıkartılmış ve görüntü işlemeye hazırlanmıştır. Yapılan kontrollü siniflama neticesinde tarım, orman, mera, su yüzeyi ve tarım dışı olmak üzere beş adet arazi kullanım türü Erdas ortamında belirlenmiştir.

Arazi kullanım etkinliğinin belirlenmesi için ArcGIS ortamında piksel bazlı bir siniflama sistemi gerçekleştirilmiş; 1982 yılına ait sayısal toprak haritasında bulunan vektörel veriler ArcGIS 9.3 yazilıminın "Raster calculator" arac1 kullanılarak raster formatına dönüştürülmüştür. Arazi kullanım kabiliyet sinıflamasinda bulunan sınıfların 1982 ve 2012 yılı arazi kullanım türlerinin üzerine çakıştırılmasıyla kıyaslamalar yapılmış ve arazilerin ne kadarının potansiyeli doğrultusunda kullanıldığ 1 ortaya çıkarılmıştır. Alansal ve oransal değerlerin belirlenmesi ile mevcut yillar arasındaki zamansal değişim açıklanmıştır.

\section{Bulgular ve Tartış ma}

Ezine ilçesinin 1982 y1lı verileri sonucu oluşturulmuş arazi kullanım kabiliyet sınıflamasına ait bilgiler Tablol'de sunulmuştur (Anonim, 1999).

Tablo 1. Ezine'ye ait arazi kullanım kabiliyet siniflamas 1

\begin{tabular}{lcc}
\hline AKK & Alan (ha) & Alan (\%) \\
\hline I & 2883.00 & 3.99 \\
II & 13837.00 & 19.17 \\
III & 7588.00 & 10.51 \\
IV & 10624.00 & 14.72 \\
VI & 16320.00 & 22.61 \\
VII & 19250.00 & 26.67 \\
VIII & 1685.00 & 2.33 \\
\hline Toplam & 72187.00 & 100.00 \\
\hline AKK: Arazi Kullanım Kabiliyet Sinff &
\end{tabular}


Tablo 1 verileri incelendiğinde; araziler iş lemeli tarıma uygun olup, ilk dört sinıfta yer alan araziler Ezine ilçesinin \% 48.39'unu, işlemeli tarıma uygun olmayan ve son üç (VI., VII. ve VIII. sinıf araziler) sinıfa dahil araziler ise çalışma alanının \% 51.61'ini oluşturmaktadır. AKK verilerine göre oransal olarak en fazla alana sahip araziler sirasiyla VII. ve VI. siniflar olup, VIII. ve I. sınıf arazilerin ise oransal olarak en az değere sahip olduğu görülmektedir.

Çalışmada, 1982 yılı verileri sonucunda üretilmiş arazi kullanım türlerinin haritası Şekil 3’te verilmiştir. Beş farklı arazi kullanım türünün tanımlandığ1 Şekil 3 verileri incelendiğinde; Ezine ilçesine ait arazilerin \% 47.68'i tarım, \% 13.83'ü mera, \% 35.00'1 orman, \% 0.23 'ü su yüzeyleri ve $\%$ 3.25'inin ise tarım dışı arazilerden oluştuğu görülmektedir (Tablo 2).

Şekil 4'te, 2012 yılına ait uydu görüntüsünün sinıflandırılması sonucu üretilen ve arazi kullanım türlerinin tanımlandığ1 harita yer almaktadır. 2012 yılı verilerine göre Ezine ilçesinde bulunan arazilerin \%58.50'si tarım, \% 14.38'i mera,
$\%$ 23.28'i orman, \% 0.26 's1 su yüzeyleri ve $\%$ 3.57'sinin ise tarım dişı arazilerden oluştuğu görülmektedir (Tablo 2). $\mathrm{Bu}$ veriler, Say1 (2013)'nin verileriyle de uyumluluk göstermektedir.

Şekil 5-8'de 1982 yllındaki arazi kullanım türlerinin etkinliğinin incelenmesi için raster formatına dönüştürülmüş $\mathrm{AKK}$ haritası her bir arazi kullanım türleri (AKT)'nin (tarım, orman, mera ve tarım dişı) üzerine aktarılmış ve sunulmuştur. "Raster calculator" aracı ile yapılan hesaplamalara ait analiz sonuçları Tablo 2'de sunulmuştur. Yapılan analiz sonucunda; I., II., III ve IV. sinif arazilerin sirasiyla \% 94.00, \% 87.87, $\% 64.47$ ve \% 80.68 gibi oranlarda tarım arazisi olarak kullanıldığ1; orman arazilerinin, VI. ve VII. sinif alanlarda \% 67.48 ile \% 49.29'luk bir paya sahip olduğu; mera arazi kullanım türüne ait alanların ise, en fazla VI. ve VII. (1346 ha ve 7699 ha) sınıf arazilerde olduğu görülmektedir. Tarım dışı araziler ile su yüzeylerinin ise VIII. sınıf araziler içinde (\% 90.27 ve $\% 9.73$ ) tanımland ${ }^{\breve{g}} 1$ belirlenmiştir.

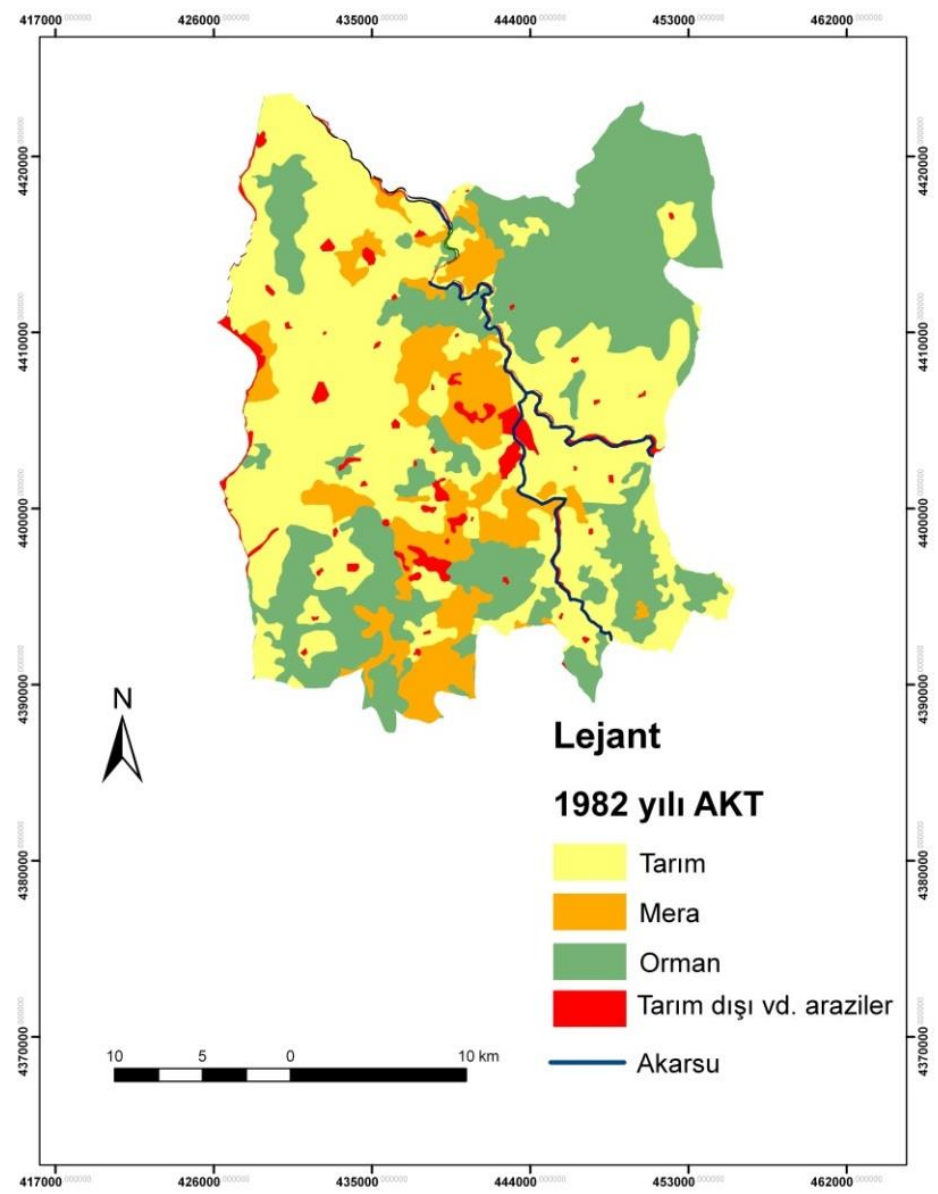

Şekil 3. 1982 y1lına ait Ezine ilçesi arazi kullanım türleri 


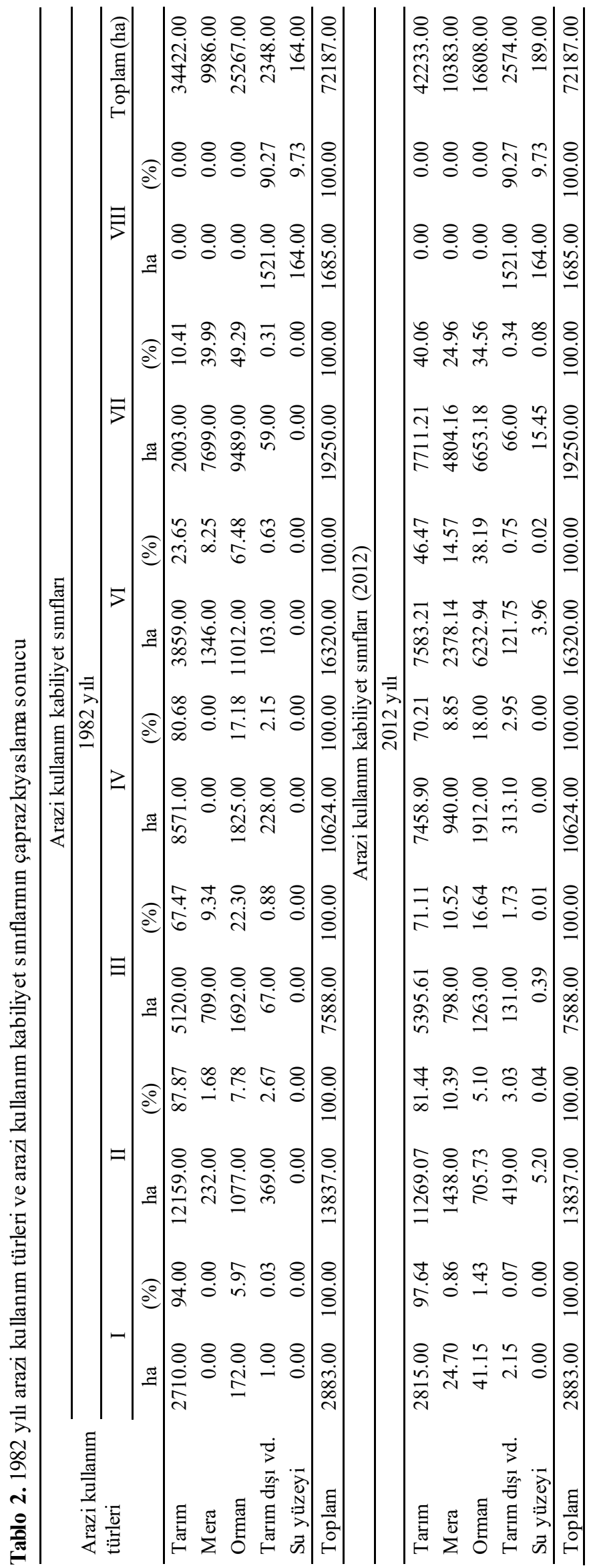




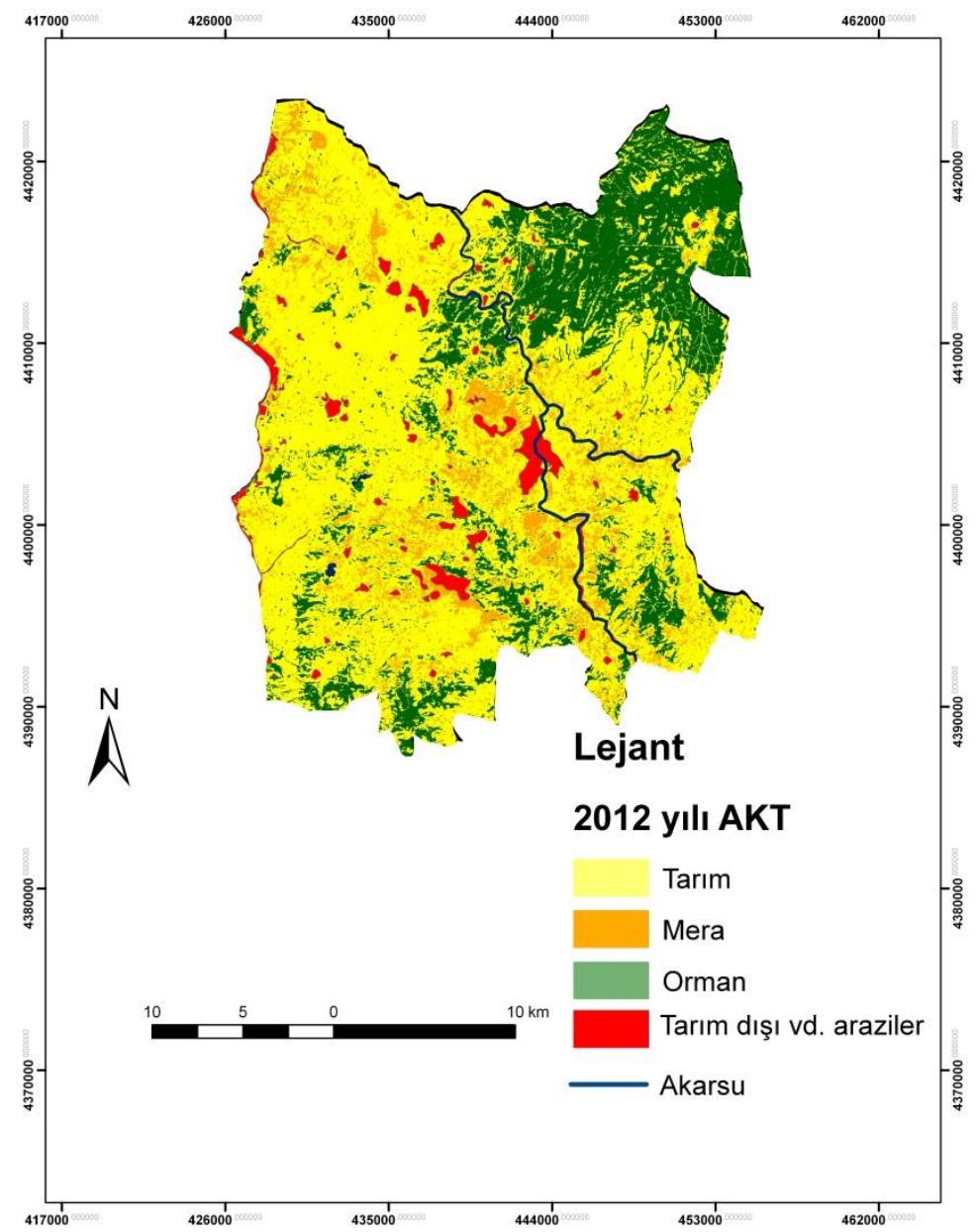

Şekil 4. 2012 yılına ait Ezine ilçesi arazi kullanım türleri

Çalışmada; 2012 yılı arazi kullanım etkinliğinin belirlenmesi için raster formatına dönüştürülmüş AKK haritası ve 2012 sinıflandırılırmış uydu görüntüsü üst üste çakıştırılmış ve Şekil 5-8'de verilmiştir. Yapılan hesaplamalar sonucunda I., II., III., IV., VI. ve VII. sinif arazilerin sirasiyla \% $97.64, \quad \% \quad 81.44$, $\% 71.11, \% 70.21, \% 46.47$ ve \% 40.06'llk oranlar ile tarım arazisi olarak kullanıldığı görülmektedir. VI. ve VII. sinıf arazilerde orman alanları \% 38.19 ve \% 34.56'lik alan kaplamaktadır. Mera alanları ise bütün siniflarda \% 0.86-24.96 arasında değişim göstermektedir.

Araştırmada; 1982 ve 2012 yılları arasındaki 30 senelik dönemde meydana gelen değişimlerin rakamsal kiyaslanmas1 (Tablo 3), grafiksel gösterimi (Șekil 9) ve arazi kullanım türlerinin arazi kullanım kabiliyet sınıfları ile kıyaslanması (Şekil 10) da yapılmıştır. Tablo verileri incelendiğinde I. sınıf tarım arazilerinde 1982 yılinda tarım arazileri 2710 ha iken, 2012 yılında 2815 hektara yükselmiştir. Mera alanları I. sınıf arazilerde 1982 yılında hiç yok iken, 2012 yılında 24.70 hektarlık bir artış göstermiştir. Orman alanları ise 172 hektardan 41.15 hektara gerilemiştir. Tarım dışı araziler 1982 yılında 1 ha yüzölçümüne sahip iken, 2012 yılında 2.15 ha olmuştur. I. sınıf tarım arazilerinde özellikle orman alanlarının tahrip edilerek mera ve tarım arazisi olarak kullanıldığı görülmektedir. Tarım dış1 alanlarda ise 1.15 hektarlık bir artış olmuştur (Tablo 3).

Tarım amaçlı arazi kullanımi; II. sınıf arazilerde 1982 yılında 12159 ha iken, 2012 y1lında 11269.07 hektara gerilemiștir. Mera alanları 232 hektardan 1438 hektara, tarım dış1 alanlar ise 369 hektardan 419 hektara yükselmiştir. 1982 yılında hiç su yüzeyi bulunmazken, 2012 y1lındaki değerlendirme sonucu 5.20 ha olduğu belirlenmiştir. Orman alanları ise 1077 hektardan 705.73 hektara gerilemiștir. II. sinıf arazilerde orman ve tarım kullanım alanlarında azalma, mera ve tarım dışı alanlarda artış görülmektedir. Yıllar 


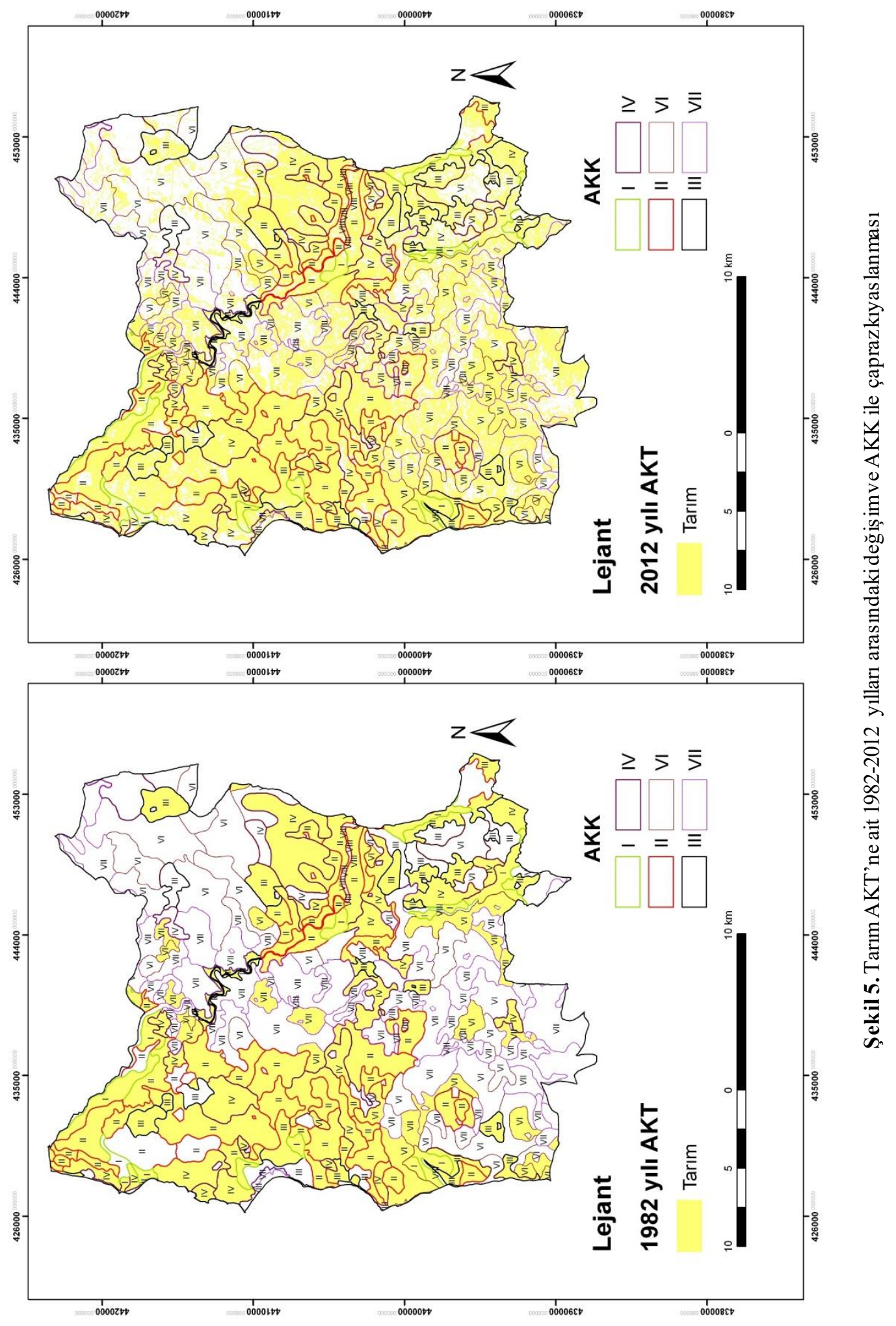




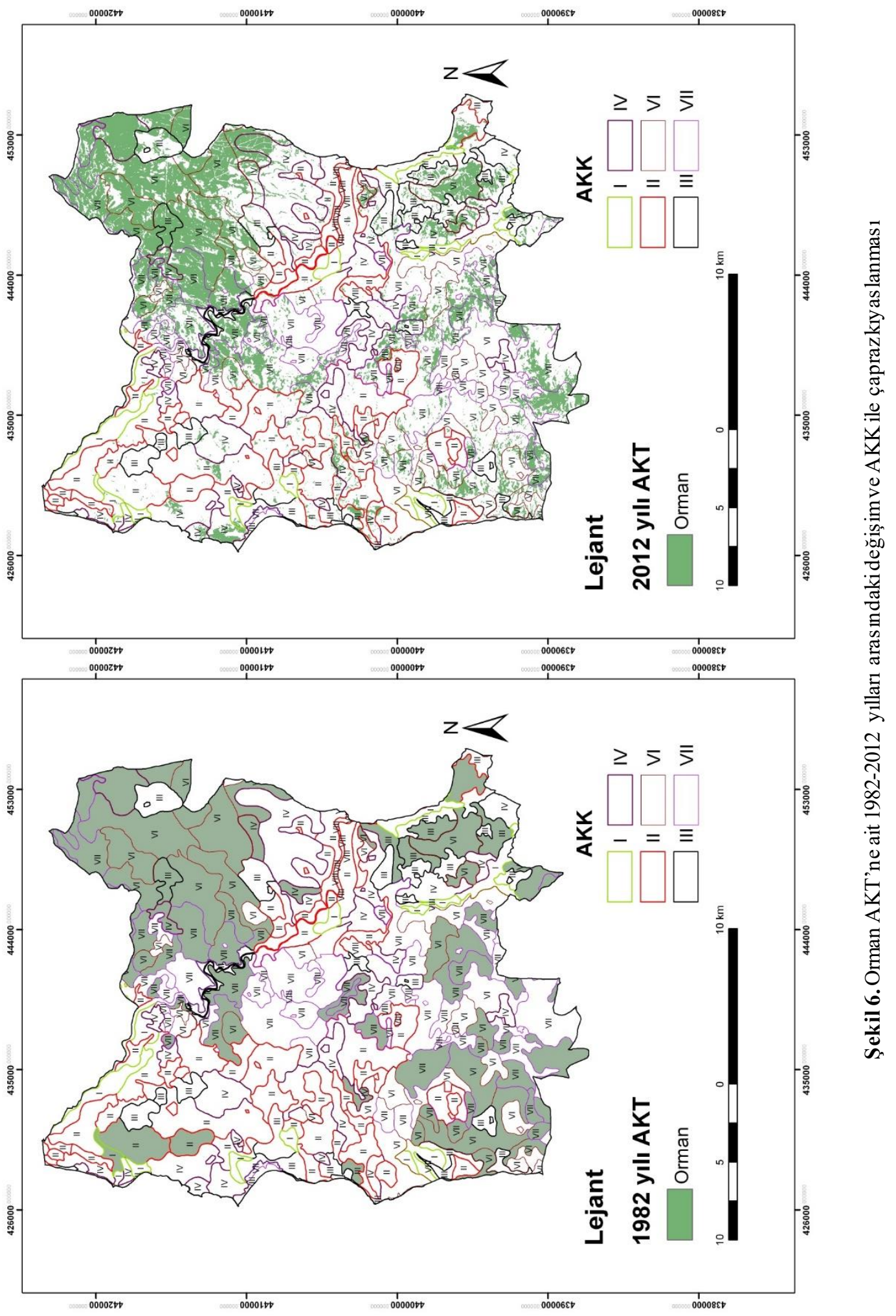




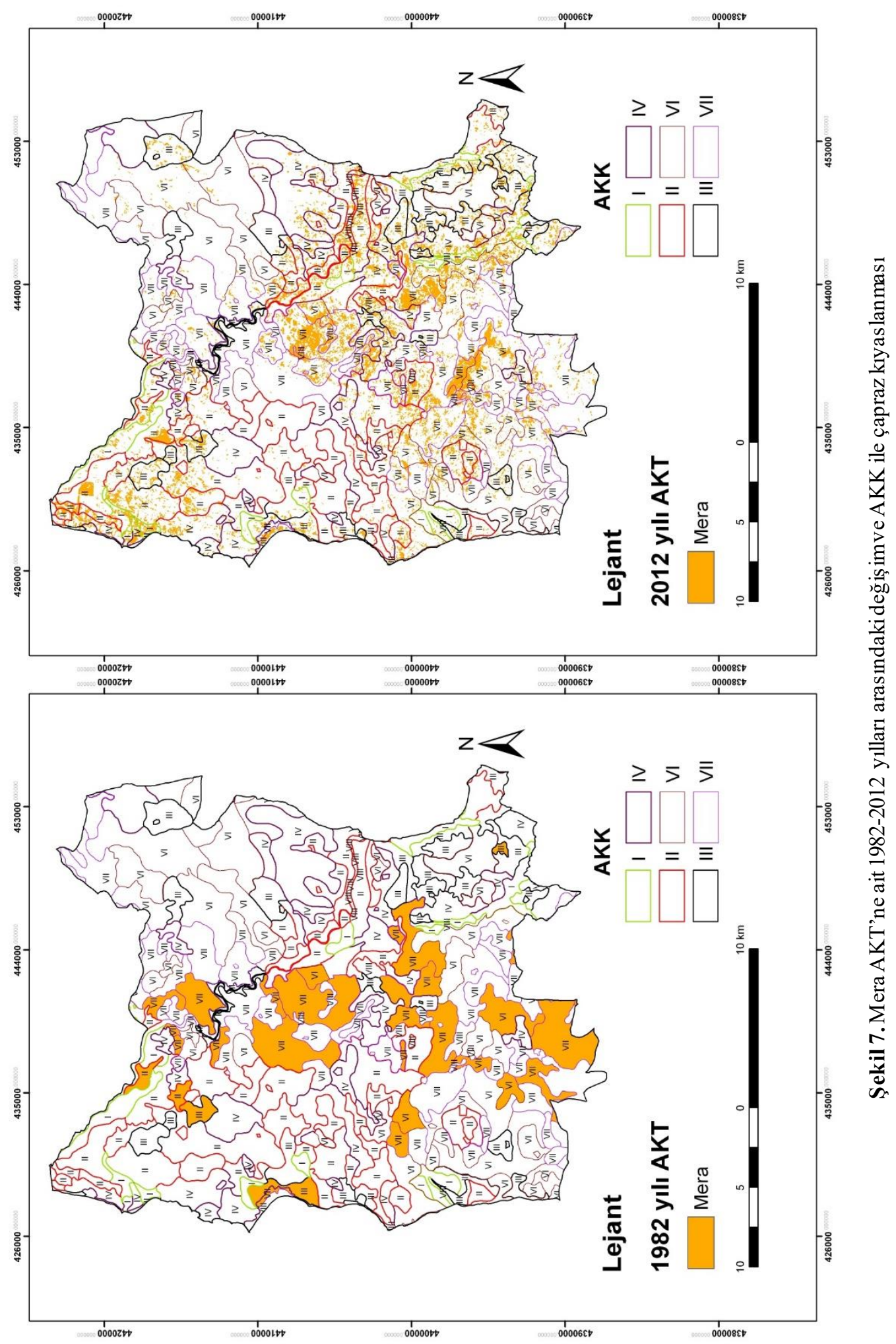




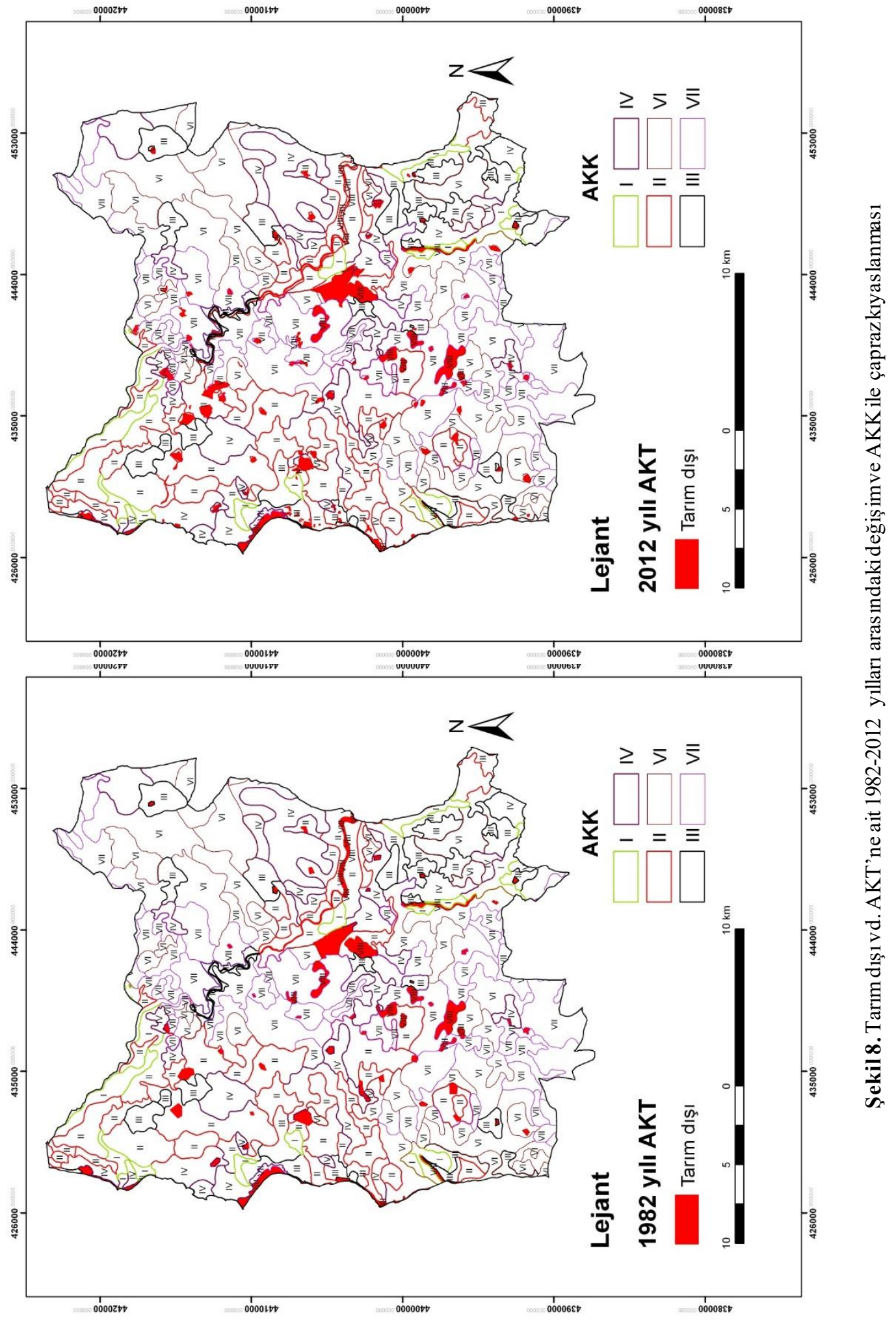



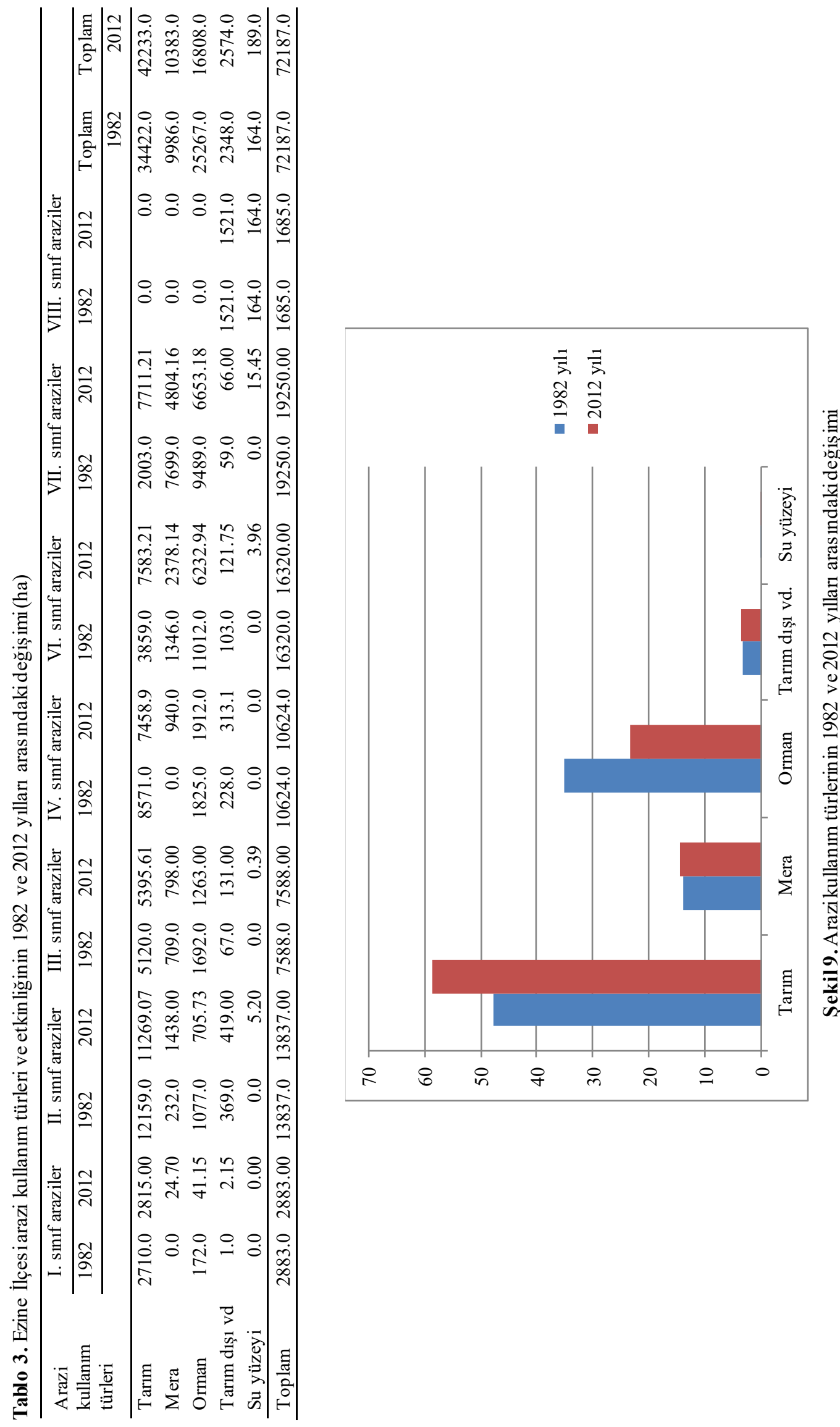


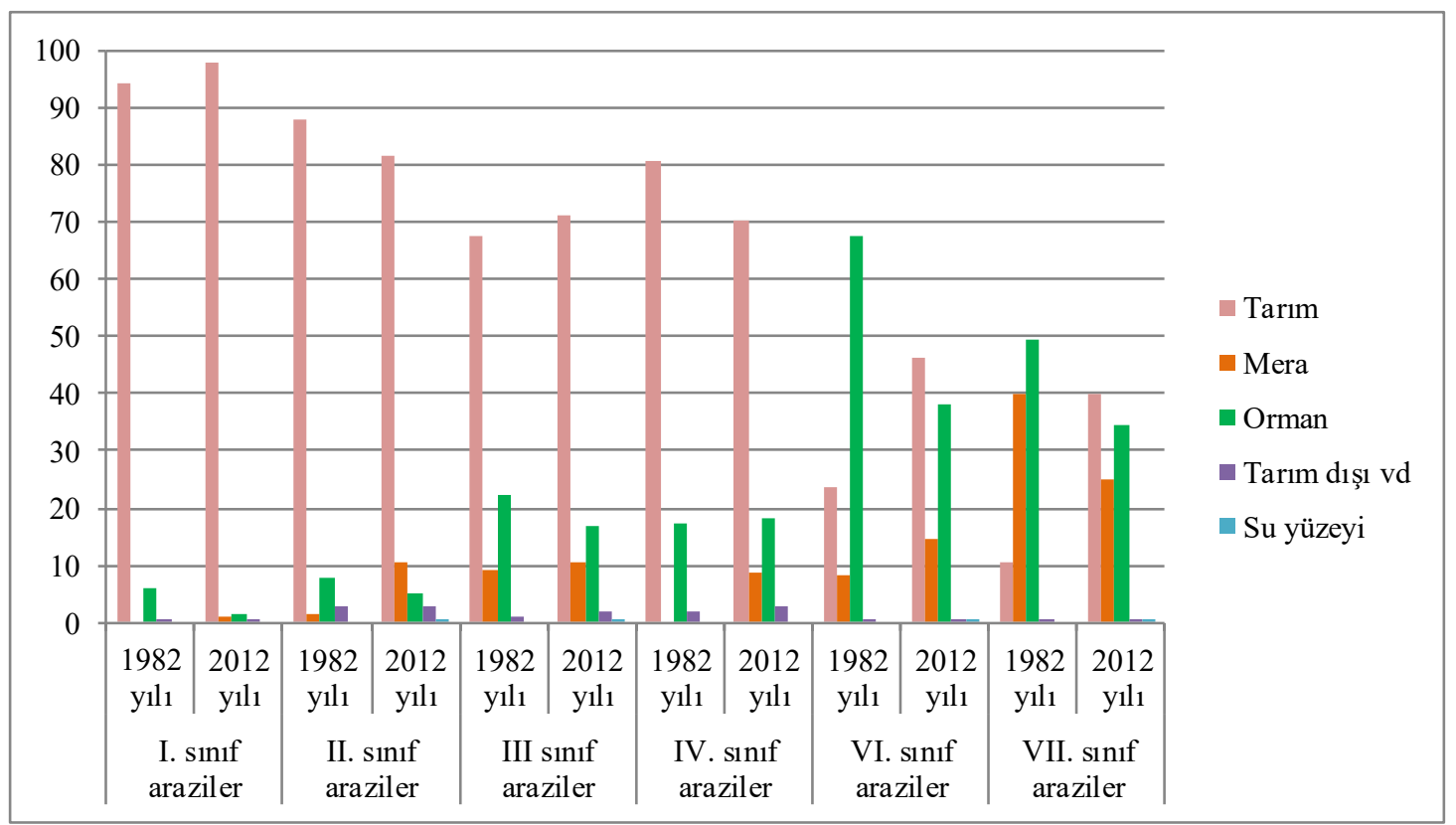

Şekil 10. 1982-2012 yılı arazi kullanım türlerinin AKK ile kıyaslanmas ına ait grafik

içinde tesis edilen gölet ve regülatör gibi tesislerde su yüzeylerinde artışa neden olmuştur (Tablo 3).

Tarım arazisi AKT; 1982 yılında III. sinif arazilerde 5120 hektar iken, bu rakam 2012 yilında 5395.61 ha olmuştur. Mera alanları 709 hektardan 798 hektara, tarım dişı kullanımlar ise 67 hektardan 131 hektara yükselmiştir. Su kütleleri 1982 yılında hiç bulunmazken, 2012 yılında 0.39 ha alan kapladığı görülmektedir. Orman alanları ise 30 yıllık süreçte 1692 hektardan 1263 hektara gerilemiştir. III. sınıf arazilerde özellikle orman alanlarının azaldığ 1 ve bununla ters orantılı olarak tarım, mera ve tarım dişı kullanımın arttığ1 görülmektedir. Tesis edilen su muhafaza yapıları ile su yüzeylerinin arttığı görülmüştür (Tablo 3).

Arazi kullanımın etkinliği IV. sınıf arazilerde incelendiğinde; tarım arazilerinin 8571 hektardan 7458.90 hektara gerilediği görülürken; bunun aksine mera alanlarının 0 hektardan 940 hektara, orman alanlarinın 1825 hektardan 1912 hektara ve tarım dıșı kullanımların 228 hektardan 313 hektara yükseldiği görülmüştür. IV. sınıf tarım arazilerinde tarım alanlarından yaşanan kayıpların mera, orman ve tarım dışı kullanımlar için kullanıldığ 1 görülmektedir (Tablo 3).

Arazi kullanımı VI. sinıf tarım arazilerinin incelendiğinde; tarım (3859 hektardan 7583.21 hektara), mera (1346 hektardan 2378.14 hektara), su yüzeyleri (0 hektardan 3.96 hektara) ve tarım dış1 arazilerin (103 hektardan 121.75 hektara) yükseldiği; bunun aksine orman alanlarının, 11012 hektardan 6232.94 hektara gerilediği belirlenmiştir. VI. sınıf arazilerinde genel olarak orman alanları azalırken, diğer bütün sınıfların arttığ1 ve tesis edilen su muhafaza yapıları ile su yüzeylerinin arttığı izlenmiştir (Tablo 3 ).

Tarım alanlarında özellikle VII. sınıfa ait arazilerde çok ciddi anlamda bir artış olurken (1982 y1l 2003 ha, 2012 y1l 7711.21 ha), bunun aksine mera (1982 y1l 7699 ha, 2012 y1l 4804.16 ha) ve orman (1982 yılı 9489 ha, 2012 yıl 6653.18 ha) arazilerinde azalmaların olduğu görülmektedir. Tarım dış1 kullanımlar 30 yıllık süreçte 59 hektardan 66 hektara artış gösterirken, tesis edilen su muhafaza yapıları ile su kütlelerinin 2012 yılında 15.45 ha alan kapladığı görülmüştür. İlk yedi sınıf için yapılan değerlendirmeler farklı araştırmacıların yaptığı çalışmalar ile (Akbulak ve ark., 2010; Everest ve ark., 2011; Dengiz ve Turan, 2014) benzerlik göstermektedir (Tablo 3).

KHGM tarafindan 1982 yılında yapilan çalışmada VIII. sınıf araziler ırmak yatağı, çıplak kayalık, maden ocakları, kumullar gibi kullanımlar olarak tanımlanmış ve tarım dışı kullanımlar ile su yüzeyleri bu alanlara ilave edilerek sinıflandırılmıştır. VIII. sınıf arazilerin 30 yıllık değişimi bu anlamda değerlendirilmemiş, özellikle tarım dışı kullanım ile su kütlelerinin artışı ilk yedi sınıf içinde meydana gelen değişim incelenerek irdelenmiştir (Tablo 3).

\section{Sonuçlar}

$\mathrm{Bu}$ çalışmada yaklaşı $721 \mathrm{~km}^{2}$ yüzölçümüne sahip Ezine ilçesi arazi kaynaklarının (1982-2012) 
yılları arasındaki değişimi incelenerek arazi kullanım etkinliği belirlenmiștir. Yapılan analizler ile elden edilen veriler doğrultusunda I., II. ve III. sınıf arazilerde özellikle tarım alanlarının arttığ görülmüştür. Tarım alanlarındaki artış orman alanlarındaki azalmaya bağlı olarak gelişmiştir. Özellikle ilk üç sınıf içinde bulunan arazilerde tarım dişı kullanımlarda artışı olduğu gözlenmiștir. Tarım dışı alanlardaki artış özellikle kentsel gelişimdeki artıştan kaynaklanmaktadır. Ezine ilçesinin deniz kıyısı yerleşiminde bulunan ve yazlık ile ikincil konut olarak kullanılan bölgelerdeki artış tarımsal amaçlı kullanılması gereken alanlardaki azalmalara sebep olmuştur. Çalışmada bütün siniflarda tarım dișı kullanımlarda artışın olduğu gözlenmiştir. IV., VI. ve VII. sınıf arazilerde meydana gelen tarım dişı kullanımdaki artış özellikle köy yerleşimlerinin gelișmesi ve maden ocağ 1 faaliyetlerinin artması ile meydana gelmiştir.

Tarım dışı kullanımların özellikle ilk dört sınıf içinde artması ilçede arazi degradasyonunda artışını göstermektedir. I sınıf tarım arazilerinde 1982 yılında 1 ha olan tarım dış1 kullanım, 2012 yılı verilerine göre 2.15 hektara yükselmiştir. I. sınıf tarım arazilerinin büyük bir bölümü çalışma alanının kuzeyinde bulunan ve 1996 yılından itibaren "Troya Tarihi Milli Parkı" olarak kullanılan bölgenin içinde yer almaktadır. Özellikle 1996 y1lı ve sonrasinda bu alanlarda tarım dışı kullanımlara "Milli Park" statüsü nedeniyle izin verilmemektedir. Bu alan özelinde olduğu gibi mutlak tarımsal amaçlı kullanılması gereken alanlar ilgili kurumlar ve paydaşların katkı1 ile 5403 sayılı "Toprak Koruma ve Arazi Kullanım Kanunu" uyarınca tanımlanmalı ve tarım dışı kullanımların önüne geçilmelidir.

Çalışmada bir diğer dikkat çekici husus da, orman alanlarındaki azalmalardır. 1982 yılında toplam 25267 ha olan orman alanlar1 2012 y1linda 16808 hektara gerilemiştir. III. ve IV. sınıflar hariç bütün sınıflarda orman alanları azalmış ve bunun aksine mera ve tarım arazisi kullanımının arttığ1 görülmüştür. VI. ve VII. sınıf arazilerde mera ve orman arazileri azalmış ve tarım alanları artmıştır. $\mathrm{Bu}$ alanlardaki özellikle mera ve orman arazilerindeki artışlar çok ciddi problemlerin tetikleyicisi olabilir. VI. ve VII. sinifa ait alanlar sığlik ve eğim probleminin bulunduğu alanlardır. $\mathrm{Bu}$ alanlar üzerindeki yoğun orman örtüsünün ve mera kullanımının tahrip edilerek tarımsal amaçlı kullanılmas1 erozyon riskini doğuracak ve mevcut alanlardaki topraklarda kayıpların yaşanmasına neden olacaktır.

Toprak kaynaklarının efektif ve sürdürülebilir olarak kullanılması için mutlaka detaylı toprak etüt ve haritalama çalışmalarının yapılması gerekmektedir. Topraklarm olumlu-olumsuz özelliklerinin belirleneceği bu çalışmalar sonucu yapılacak arazi kullanım planlamaları ile bu kaynakların optimum kullanımı sağlanacaktır. Yapılacak bu plan ve projeksiyonlarda bütün paydaşların fikri ve verileri alınarak planlama zenginleştirilmeli ve anlamlandırılmalıdır. Özelikle bu alanlarda tarım dıșı kullanıma uygun alanlar belirlenmeli ve mutlak tarım arazileri üzerindeki baskı kaldırılmalıdır.

\section{Kaynaklar}

Akbulak, C., Özcan, H., Güre, M., 2010. Land use efficiency of the Karamenderes Basin (NW Turkey). Conference on Water Observation and Information System for Decision Support, 25-29 May, Ohrid Republic of Macedonia, pp. 633-640.

Anonim, 1999. Çanakkale İli Arazi Varlığı. T.C. Başbakanlık Köy Hizmetleri Genel Müdürlüğü Yayınları, İl Rapor No: 17, Ankara.

Anonim, 2015a. Adrese Dayalı Nüfus Kayıt Sistemi Nüfus Sayım Sonuçları. Türkiye İstatistik Kurumu, www.tuik.gov.tr (Erişim tarihi: 19.10.2015).

Anonim, 2015b. Meteoroloji Genel Müdürlüğü meteorolojik istatistik verileri. www.mgm.gov.tr (Erişim tarihi: 12.09.2015).

Anonymous, 1976. A Framevork for Land Evaluation: Soils Bulletin 32, Food and Agriculture Organization of the United Nations, Rome-Italy.

Anonymous, 1993. Guidelines for Land-Use Planning, FAO Development Series 1 ISSN 1020-0819, Food and Agriculture Organization of the United Nations, Rome-Italy.

Cangir, C., Kapur, S., Boyraz, D., Akça, E., 1998 Türkiye'de arazi kullanımı, tarım topraklarının sorunları ve optimum arazi kullanım politikaları. $M$. Sefik Yeșilsoy International Symposium on Arid Region Soil, 21-24 Eylül, Menemen-İzmir, Turkey, s. 9.

Dengiz, O., Turan, İ.D., 2014. Uzaktan Algilama ve Coğrafi Bilgi Sistem teknikleri kullanılarak arazi örtüsü/arazi kullanımı zamansal değiş̧imin belirlenmesi: Samsun Merkez ilçesi örneği (19842011). Türkiye Tarımsal Araştırmalar Dergisi, 1(1): 78-90.

Dengiz, O., Usul, M., Keçeci, M., 2006. Atatürk Orman Çiftliği arazilerinin tarımsal kullanım durumlarının değerlendirilmesi. Ondokuz Mayls Üniversitesi Ziraat Fakültesi Dergisi, 21(1): 55-64.

Everest, T., 2015. Truva Tarihi Milli Park1 arazilerinin detaylı toprak etüt ve haritalanması ile arazi değerlendirmesi. Doktora tezi, Çanakkale Onsekiz Mart Üniversitesi, Fen Bilimleri Enstitüsü, Çanakkale.

Everest, T., Akbulak, C., Özcan, H., 2011. Arazi kullanım etkinliğinin değerlendirilmesi: Edirne ili Havsa ilçesi örneği. Anadolu Tarım Bilimleri Dergisi, 26(3): 251-257. 
Kayan, İ., 2000. The Water Supply of Troia. Studia Troica, Verlag Philipp von Zabern, Mainz am Rhein, pp. 135-144.

Sayı, Ö., 2013. Çanakkale ili arazi kullanım ve bitki örtüsü değişiminin uzaktan alglama yardımı ile belirlenmesi. Yüksek lisans tezi, Çanakkale
Onsekiz Mart Üniversitesi, Fen Bilimleri Enstitüsü, Çanakkale.

Thornthwaite, C.W., 1948. An approach to a rational classification of climate. Geographic Review, 38: 55-94. 